\title{
KINETIC STUDIES ON THE SYNTHESIS OF ALKYL DIETHANOLAMIDE FROM Terminalia catappa L. SEED OIL
}

\author{
E.R. Gunawan ${ }^{1}$, D. Suhendra ${ }^{1,}$, , S.A. Iliyin ${ }^{1}$ and L. Kurniawati ${ }^{1}$ \\ ${ }^{1}$ Department of Chemistry, Faculty of Mathematics and Natural Sciences, University of \\ Mataram, J1. Majapahit No. 62 Mataram, NTB Indonesia \\ ${ }^{凶}$ E-mail : dedysuhendra@unram.ac.id
}

\begin{abstract}
The main objective of this research is the experimental investigation of the reaction kinetics of the synthesis of alkyl diethanolamide and the determination of its kinetic constants. The reaction parameters, such as the amount of lipase and substrate concentration were examined. The results showed that the enzymatic synthesis of alkyl diethanolamide with the substrates of ketapang (terminalia catappa $L$ ) seed oil and diethanolamine followed the Michaelis-Menten kinetics model. Importantly, $K_{m}$ values for ketapang seed oil and ethanolamine substrates were $0.43 \mathrm{mmol}$ and 14.55 mmol, respectively. The $V_{\max }$ value for the synthesis of alkyl diethanolamide reaction was $1.57 \times 10^{-5} \mathrm{mmol}^{-\mathrm{min}^{-}}$ ${ }^{1} . \mathrm{mg}^{-1}$ Catalyst. The mechanism of the synthesis of alkyl diethanolamide reaction follows the kinetic mechanism of Bi-Bi Ping-Pong.
\end{abstract}

Keywords: Kinetic Studies, Alkyldiethanolamide, Terminalia catappa L. Seed Oil, Enzymatic Reaction

RASĀYAN J. Chem., Vol. 14, No.4, 2021

\section{INTRODUCTION}

Alkyl diethanolamide is one of the amide fat compounds that have an $\mathrm{RCON}\left(\mathrm{CH}_{2} \mathrm{CH}_{2} \mathrm{OH}\right)_{2}$ structure with polarity dualism. There is a hydrophobic nature resulting from the presence of alkyl (R) and hydrophilic chains due to the diethanolamide group. As a result of this dualism, its molecule appears in the water-oil interface and reduces the surface tension. For this reason, Alkyl diethanolamide is used as a surfactant in various cosmetics and pharmaceutical industries. ${ }^{1-3}$

Generally, surfactants are synthesized from petroleum oil, though the end product is likely to poison the ecosystem ${ }^{4}$. Alternatively, environmentally friendly materials such as vegetable oil (edible and non-edible oil) have the potential to be used as a feedstock. For instance, palm oil $1^{5,6}$ and coconut oil ${ }^{7}$ are widely used in the production of surfactants. However, non-edible oils such as jatropha ${ }^{8}$ and passiflora ${ }^{9}$ have also been used as a feedstock in the synthesis of alkanolamide surfactants using chemical catalysts. Nevertheless, the chemical catalysts are not selective, difficult to separate from the product, toxic, need high pressure and temperature, and long reaction time. ${ }^{10,11}$ Another type of catalyst that is more recommended is the enzyme catalyst. For example, previous studies ${ }^{12}$ have successfully synthesized alkyl diethanolamide using the lipase enzyme at relatively low reaction temperatures and shorter times than chemical catalysts. In the use of an enzyme catalyst in a synthesis reaction by itself, it must be considered the kinetics of the enzyme.

Enzyme kinetics involves determining reaction rates and the factors which affect them, such as substrate concentration, reaction temperature, and amount of enzymes. In general, the factors influencing the rate of enzyme catalyzed reactions are described using the Michaelis-Menten equation ${ }^{13}$. The enzymes increase reaction rates and specificity, which is the ability to selectively catalyze certain reactants or substrates. Also, information about substrate concentration is essential in the study of enzymatic kinetics. It is related to the constant value of Michaelis-Menten $\left(K_{m}\right)$, which is, the concentration of the substrate producing a reaction rate half times slower than the maximum rate $\left(V_{\max }\right)$ or $V_{\max } / 2 .{ }^{14}$

Our previous research successfully synthesized alkyl diethanolamide using ketapang seed oil and diethanolamine as a substrate ${ }^{12}$. Therefore, the author intended to complement the previous research by observing the reaction rate of the ketapang seed oil substrate and diethanolamine to the specificity of the lipase enzyme. The purpose of this study, furthermore, was to determine the kinetics model of enzymatic reactions in the synthesis of alkyl diethanolamide. It also aimed to determine the specificity of the lipase

Rasayan J. Chem., 14(4), 2499-2505(2021)

http://dx.doi.org/10.31788/RJC.2021.1445954

This work is licensed under a CC BY 4.0 license. 
enzyme on the substrate. The results are expected to be used as a reference for the production of alkyl diethanolamide through enzymatic catalysis.

\section{EXPERIMENTAL}

\section{Material and Methods}

Ketapang seed oil was the primary substance used in the research. Nevertheless, the study also used chemicals with a degree of pro analysis (PA) grade such as diethanolamine and hexane from Sigma Aldrich (USA); hydrochloric acid, sodium sulfate, silica gel, and methanol 98\% from Fluka Chemica (Switzerland); standard alkyl diethanolamide from Sigma Aldrich (USA); and commercial lipase (Lipozyme TL-IM / Thermomyces lanuginosus, immobilized lipase) from Novo Nordisk (Denmark).

Extraction was carried out using the soxhletation method and the process was run for $6 \mathrm{~h}$ using hexane solvent. The solvent was evaporated using a rotary evaporator at $40^{\circ} \mathrm{C}$ and a velocity of $120 \mathrm{rpm}$. In the next step, the oil was purified using a chromatography column with silica gel (stationary phase) and hexane (mobile phase).

\section{General Procedure}

The synthesis of alkyl diethanolamide was carried out by reacting ketapang seed oil and diethanolamine using hexane solvents and Lipozyme TL-IM catalyst. The mixture was incubated in a shaker water bath at $40^{\circ} \mathrm{C}$ for a certain time. The product formed in the organic phase (n-hexane) is separated from the aqueous phase using a separating funnel. Lipozyme is separated from the product by filtering. The alkyl diethanolamide gel obtained from the organic phase which is cooled for $24 \mathrm{~h}$ to less than $5^{\circ} \mathrm{C}$ is separated using a Buchner funnel and dried in a desiccator. Importantly, quantitative and qualitative analysis of the product is carried out using gravimetric, GC-MS, and FTIR methods.

\section{Effect of Enzyme Concentration}

One mmol of the seed oil was reacted with $1 \mathrm{mmol}$ of diethanolamine using $2 \mathrm{~mL}$-hexane in the concentrations of $0.05,0.10,0.15,0.20,0.25$, and $0.30 \mathrm{~g}$, and the reaction mixture was incubated at $40^{\circ} \mathrm{C}$ for $5 \mathrm{~h}$.

\section{Effect of Ketapang Seed Oil Substrate Concentration}

Ketapang seed oil concentrations of $0.5,1.5,2.5$, and $3.5 \mathrm{mmol}$ were reacted with $1 \mathrm{mmol}$ diethanolamine, $2 \mathrm{~mL}$ n-hexane, and $0.3 \mathrm{~g}$ TL-IM lipozyme. The reaction mixture was incubated at $40^{\circ} \mathrm{C}$ for $5 \mathrm{~h}$. The treatment was repeated with $2 \mathrm{mmol}$ and $3 \mathrm{mmol}$ diethanolamine.

\section{Effect of Diethanolamine Substrate Concentration}

The seed oil concentrations of $0.5,1.5,2.5$, and $3.5 \mathrm{mmol}$ were reacted with $1 \mathrm{mmol}$ diethanolamine, 2 $\mathrm{mL}$ n-hexane, and $0.3 \mathrm{~g}$ TL-IM lipozyme. The reaction mixture was incubated at $40^{\circ} \mathrm{C}$ for $5 \mathrm{~h}$. The treatment was repeated with $2 \mathrm{mmol}$ and $3 \mathrm{mmol}$ diethanolamine.

\section{Determination of The Enzymatic Kinetics Constant and The Reaction Mechanism model}

The mechanism and kinetics constant of a reaction (nilai $K_{m}$ and $V_{\max }$ ) were determined by analyzing the Michaelis-Menten curve using the Lineweaver-Burk approach, while the reaction mechanism model was established by observing the line between the initial velocity and the substrate $\left(1 / V_{o}\right.$ and $\left.1 /[\mathrm{S}]\right)$.

\section{Ketapang Seed Oil Extraction}

\section{RESULTS AND DISCUSSION}

The oil extraction using the soxhletation method and n-hexane solvent produces $63-64 \%$ of oil. Acid, iodine, and saponification values of the oil are $9.96 \mathrm{mg} \mathrm{KOH} / \mathrm{g}, 112.95 \mathrm{mg} \mathrm{I} / 100 \mathrm{~g}$ oil, and 158.48 $\mathrm{mgKOH} / \mathrm{g}$, respectively. This indicates that economically ketapang fruit might be used as a new source of triglycerides. ${ }^{15,16}$

\section{Synthesis and Purification of Alkyl Diethanolamide}

The reaction of the formation of alkyl diethanolamide occurs at the interface of the aqueous phase and the organic phase (n-hexane). This interface reaction occurs because the lipozyme TL-IM is in the interface 
phase of water and organic. The product (alkyl diethanolamide) is purified by separating the aqueous, lipase and organic phases. Purification of alkildietanolamide can be done by separating the lipase enzyme from the synthesis mixture by filtering. The next step is to separate the alkildietanolamide in the n-hexane phase with the rest of the reaction in the aqueous phase. Separation is done by using a separating funnel. In the hexane phase, in addition to the product, it is also possible that there are still unreacted triglyceride residues. Separation of alkildietanolamide is done by cooling the organic phase in the freezer $\left(-5^{\circ} \mathrm{C}\right)$ for \pm $24 \mathrm{~h}$. The purpose of this step is to reduce the solubility of alkildietanolamide, so that alkildietanolamide is not soluble in n-hexane and can be separated from the rest of the oil. This purification technique is an amalgamation of the techniques that have been carried out by Adewuy et al. ${ }^{2}$ and Gunawan et al. ${ }^{12}$

\section{Determination of Initial Reaction Velocity $\left(V_{0}\right)$ \\ The Effect of the Amount of Enzyme}

The effect of the amount of the lipase on $V_{0}$ on the synthesis of alkyl diethanolamide is shown in Fig.-1.

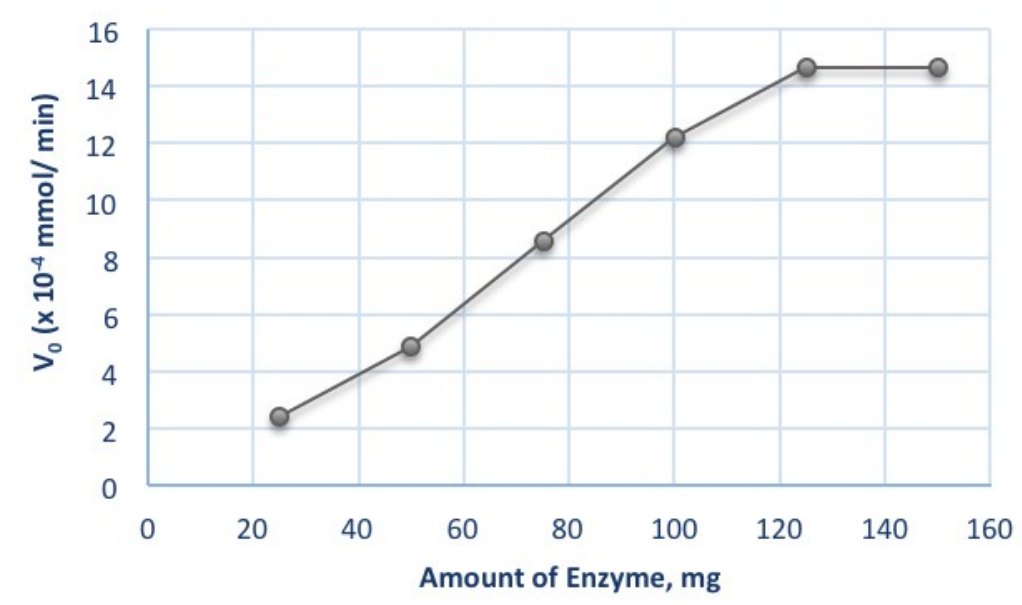

Fig.-1: Effect of the Amount of Enzyme on $V_{0}$ : Reaction Time $5 \mathrm{~h}$ at $4^{\circ} \mathrm{C}$

Figure- 1 shows the reaction velocity increases with the amount of the enzyme by $25-125 \mathrm{mg}$. This means the increase in the reaction velocity is directly proportional to the increase in the number of enzymes, a conclusion that conforms to the research conducted by Gonze and Kaufman ${ }^{17}$. Furthermore, the highest velocity of synthesis of alkyl diethanolamide is achieved at the enzyme amount of $125 \mathrm{mg}$. At this point, the forward reaction stops due to the limited amount of substrate to be changed by the lipase enzyme. Therefore, the increase in the amount of the enzyme is not directly proportional to the increase in the quantity of the product ${ }^{18}$.

\section{Effect of Ketapang Seed Oil Concentration}

The effect of variations in the concentration of ketapang seed oil on the initial rate of reaction was observed by varying its concentration (fixed diethanolamine concentration). Fig.-2 shows an increase in initial velocity from 0.5 to $3.5 \mathrm{mmol}$ concentration of ketapang seed oil and $1 \mathrm{mmol}$ of diethanolamine. The same pattern also occurs at concentrations of 2 and $3 \mathrm{mmol}$ of diethanolamine. The initial rate of reaction between oil and enzymes increases with an increase in the concentration of diethanolamine. This is due to an increase in substrate concentration to the level which saturates the enzymes. At this point, all the enzymes are Enzyme-substrate complexes, and therefore cannot increase reaction rate since they are not free. Fig.-2 illustrates the synthesis of alkyl diethanolamide following Michaelis-Menten's kinetics. Generally, the relationship between initial rate and hyperbole substrate is common in enzymatic reactions. ${ }^{17,19}$

\section{Effect of Variations in the Concentration of Diethanolamine}

The effect of variations in the concentration of diethanolamine on the initial velocity of the reaction was determined by varying the intensity of diethanolamine while setting the ketapang seed oil to constant. 
RASĀYAN J. Chem.

Vol. 14 | No. 4 |2499-2505| October- December | 2021

Fig.-3 shows the same pattern as Fig.-2 shown earlier. This proves that the synthesis of the alkyl diethanolamide reaction is in line with the Michaelis-Menten kinetics model.

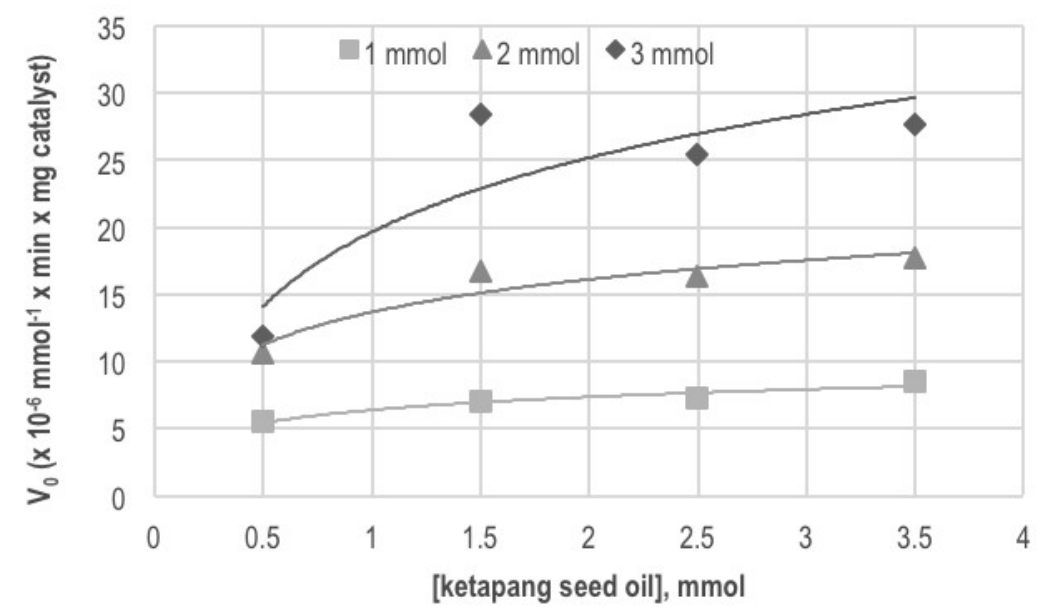

Fig.-2: Initial Velocity Reaction of Synthesis of Alkyl Diethanolamide as a Function of Ketapang Seed Oil Concentration

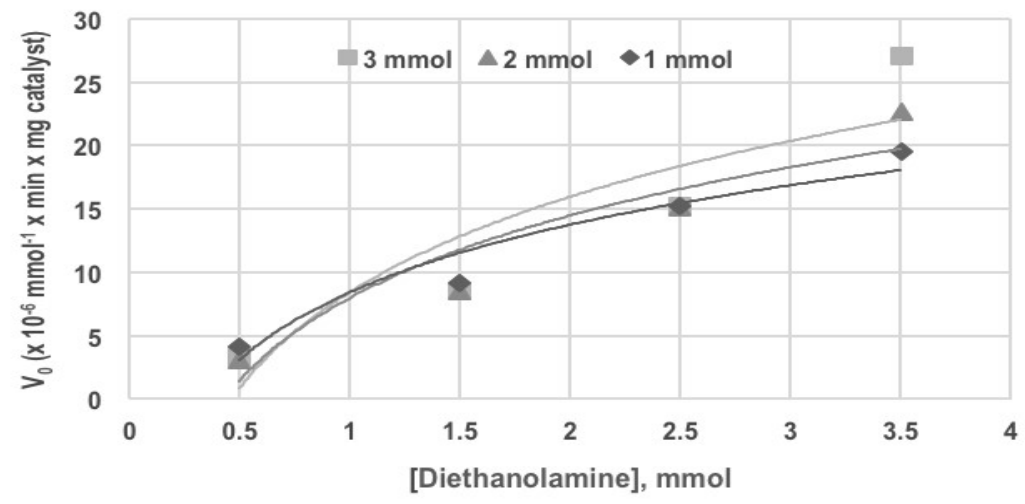

Fig.-3: The Initial Velocity of the Synthesis of Alkyl Diethanolamide as a Function of Diethanolamine Concentration

\section{Determination of the Mechanism and Kinetics of Reaction}

The synthesis of alkyl diethanolamide reaction involves two substrates, ketapang seed oil and diethanolamine. Generally, a two-substrate reaction involves three types of bi-reaction mechanism which differ according to the order of substrate participation and product release during enzymatic reactions ${ }^{13}$. In the reaction involving two substrates, the Michaelis-Menten equation has a hyperbolic curve with a limit value. This is attributed to the saturation of enzyme by substrate, where any addition continuously exceeds the capacity of the enzyme. Therefore, to determine various identities of the specificity of an enzyme, such as $K_{m}$ and $V_{\max }$ scores, a modification to the Michaelis-Menten equation, Lineweaver-Burk equation, is needed.

Figure-4 illustrates the Lineweaver-Burk line for the correlation between $1 / V_{o}$ and variations in the concentration of ketapang seed oil. Additionally, it also shows three linear lines parallel to the average value of $\mathrm{R}^{2}=0.95$. The graph indicates $K_{m}$ values for variations of ketapang seed oil by $0.0119 \times 10^{4} \mathrm{ppm}$ or $0.4352 \mathrm{mmol}$, which is smaller than the value of $K_{m}$ in the synthesis of coconut oil-based ester wax by $4.145 \mathrm{mmol}^{20}$. However, it is higher than the $K_{m}$ value in the synthesis of biodiesel with cottonseed oil substrate carried out by Gunawan et al. ${ }^{19}$ Essentially, $K_{m}$ value is used as a measure of the affinity of enzymes on the substrate. The high affinity of enzymes in a substrate means the equilibrium of the reaction form an enzyme-substrate complex and increases product recovery. Furthermore, the $K_{m}$ value also indicates the strength of the substrate binding to the enzyme molecule. The lower $K_{m}$ value means, the higher the binding capacity of the substrate to the enzyme, and vice versa. 
RASĀYAN J. Chem.

Vol. 14 | No. 4 |2499-2505| October- December | 2021

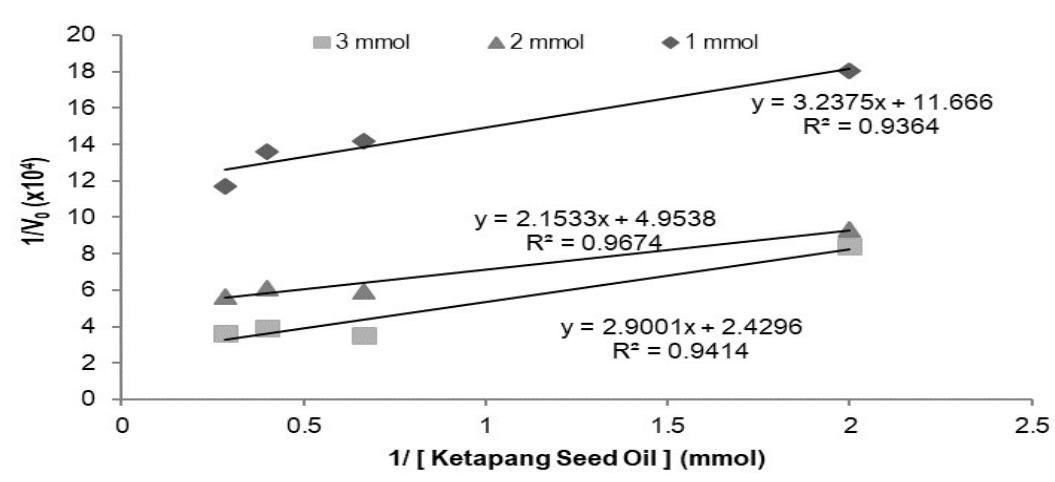

Fig.-4: Lineweaver-Burk Line for Variations of Ketapang Seed Oil Concentration

On the other hand, $V_{\max }$ obtained from Fig.-4 is $1.57 \times 10^{-5} \mathrm{mmol} / \mathrm{min} . \mathrm{mg}$ catalyst, which is smaller than the $V_{\max }$ of the palm oil alcoholysis reaction ${ }^{20}$ by $5.94 \times 10^{-3} \mathrm{mmol} / \mathrm{min} . \mathrm{mg}$ catalyst. In general, a smaller $V_{\max }$ value indicates the synthesis of alkyl diethanolamide reaction is faster than the reaction of palm oil alcoholysis. Besides, this $V_{\max }$ also shows the lipase enzyme has the potential to convert ketapang seed oil substrate to $1.57 \times 10^{-5} \mathrm{mmol}$ alkyl diethanolamide per minute. The substrate concentration determines the velocity of the enzyme reaction ${ }^{21}$. Nevertheless, an increase in substrate concentration may not necessarily increase the rate of reaction due to enzyme saturation. Fig.-4 shows the synthesis of alkyl diethanolamide reaction following the Ping-Pong Bi-Bi mechanism (shown by the graph, which tends to be linear and parallel). Generally, most enzymatic reactions of two substrates (such as triglyceride) follow the Ping-Pong Bi-Bi mechanism. 5, 19, 22

The Lineweaver-Burk line for the correlation between $1 / V_{o}$ and variations in the concentration of diethanolamine shows a $K_{m}$ value of $0.37 \times 104 \mathrm{ppm}$ or $14.55 \mathrm{mmol}$ and a $V_{\max }$ value of $10.19 \times 10^{-5}$ mmol/min.mg catalyst. The data from Fig. 4 and 5 show the differences in $K_{m}$ and $V_{\max }$ values. The $K_{m}$ value of Ketapang seed oil is smaller than the diethanolamine. This means the lipase enzyme affinity of the ketapang seed oil substrate is higher than the diethanolamine. Also, the $V_{\max }$ value of Ketapang seed oil is smaller than the diethanolamine. This means the maximum production of alkyl diethanolamide requires more diethanolamine substrate.

Figure-5 shows that the concentration of diethanolamine 2 and $3 \mathrm{mmol}$ has a parallel line while the concentration of diethanolamine $1 \mathrm{mmol}$ with $\mathrm{R}^{2}$ is slightly lower. However, this mechanism is in line with the Ping-Pong Bi-Bi reaction and the research conducted by Goterje ${ }^{22}$ which states that the increase in the slope of the curve follows the increase in acyl acceptor concentration. The Ping Pong mechanism or a non-sequential mechanism does not require two substrates to release the product.

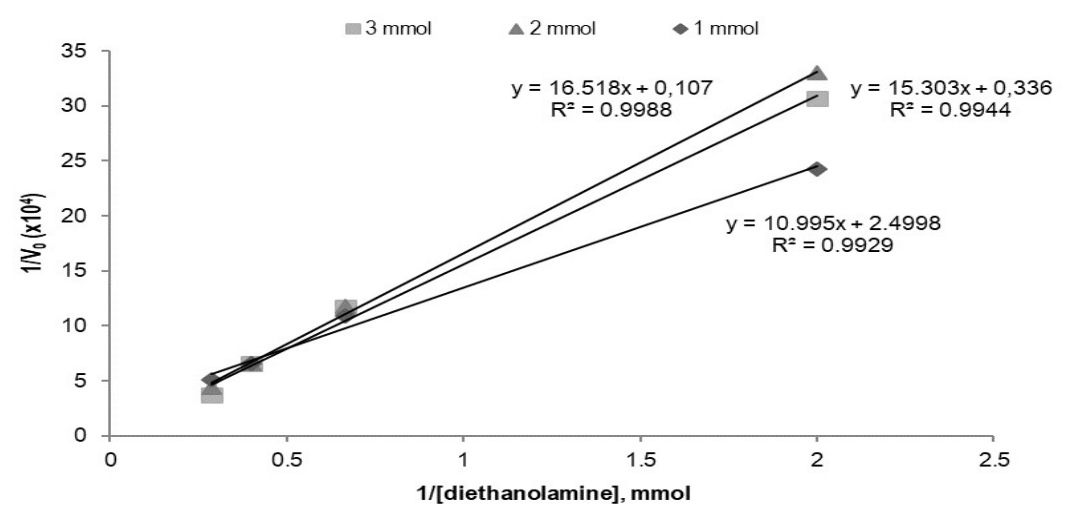

Fig.-5: Lineweaver-Burk Line for Variations in Diethanolamine Concentration

Figure-6 described kinetic mechanisms for reactions involving two substrates (A and B) and two products ( $\mathrm{P}$ and $\mathrm{Q})$. As seen in the Cleland plot notation, at least one product is released before all substrates enter. A, B, P and Q are ketapang seed oil, diethanolamine, alkil diethanolamine and glycerol. 


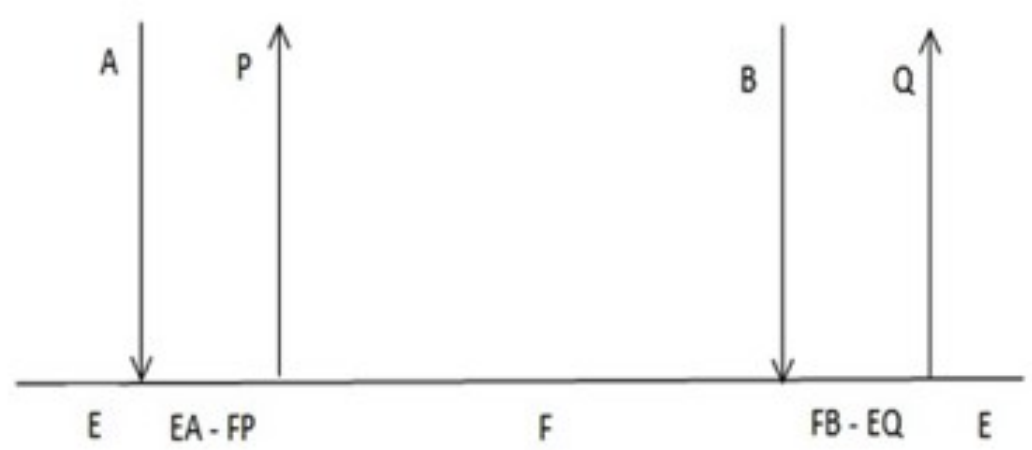

Fig.-6: Cleland Plot Notation of Ping Pong Mechanism ( $\mathrm{A}=$ Ketapang Seed Oil, $\mathrm{B}=$ Diethanolamine, $\mathrm{P}=\mathrm{Alkil}$ Diethanolamine, $\mathrm{Q}=$ Glycerol

\section{CONCLUSION}

The kinetics studies on the synthesis of alkyl diethanolamide with ketapang seed oil substrate and diethanolamine have been successfully conducted. The observation of $K_{m}$ values shows the enzyme is bound stronger to oil substrate. Based on the $V_{\max }$ values indicate the reaction between ketapang seed oil and diethanolamine occurs quicker using the Bi-bi Ping-Pong mechanism.

\section{ACKNOWLEDGEMENT}

Thanks to the 'DIKTI, Kemenristek' Republic of Indonesia for financial support, PDUPT Scheme, $2018 / 2019$.

\section{REFERENCES}

1. A. Adewuyi, Arabian. Journal of. Chemistry, 12, 1545(2019), https://doi.org/10.1016/j.arabjc.2014.10.021

2. E. R. Gunawan, D. Suhendra, Trisnasari, L. Kurniawati, Conference Series: Journal of Physics, 1095 012014 (2018), https://doi.org/10.1088/1742-6596/1095/1/012014

3. D. Suhendra, E. R. Gunawan, L. Kusumawati, Rasayan Journal of Chemistry. 12:2, 765(2019), https://doi.org/10.31788/RJC.2019.1225147

4. W. Liu, X. Wang, X. Zhou, H. Duan, P. Zhao, W. Liu, Science of The Total Environment, 702, 134593(2020), https://doi.org/10.1016/j.scitotenv.2019.134593

5. M. Basri, M. A. Kassim, R. Mohamad, A. B. Ariff, Journal Molecular. Catalysis. B: Enzymatic. 85:86, 214(2013), https://doi.org/10.1016/j.molcatb.2012.09.013

6. P. Permadi, R. Fitria, E. Hambali, Earth Conference Series:Environmental Science, 65(1), (2017), https://doi.org/10.1088/1755-1315/65/1/012034

7. G. Shan, S. Zhao, M. Qiao, N. Gao, J. Chen, Q. Ran, Construction and Building Materials, 237, 117625(2020), https://doi.org/10.1016/j.conbuildmat.2019.117625

8. D. Kumar, A. Ali, Fuel, 159, 845(2015), https://doi.org/10.1016/j.fuel.2015.07.046

9. C. G. Almeide, L. F. de Souza, R. A. Sousa, M. L. Hyaric, Catalyst Communications, 42, 25(2013), https://doi.org/10.1016/j. catcom.2013.07.037

10. A. Adewuy, Arabian Journal of Chemistry, 12(7), 1545(2019), https://doi.org/10.1016/j.arabjc.2014.10.021

11. X. Wang, Y. Cen, Q. Jin, J. Huang, X. Wang, Journal of Oleo Science, 62(6), 427(2013), https://doi.org/10.5650/jos.62.427

12. E. R. Gunawan, D. Suhendra, I. Hidayat, L. Kurniawati, Journal of Oleo Science, 67(8), 949, (2018), https://doi.org/10.5650/jos.ess 18042

13. A. G. Marangoni, (2002) Enzyme Kinetics, A Modern Approach, John Wiley \& Sons. Inc., New York, https://doi.org/10.1002/0471267295.ch7

14. R. Roskoski, (2015), Michaelis-Menten Kinetics, Reference Module in Biomedical Sciences, 1-10, https://doi.org/10.1016/B978-008055232-3.60041-8 
RASĀYAN J. Chem.

Vol. 14 | No. 4 |2499-2505| October- December | 2021

15. D. Suhendra, E. R. Gunawan, H. Hajidi, Molecules, 24, 3895(2019), https://doi.org/10.3390/molecules24213895

16. Y. Orlova, R. E. Harmon, L. J. Broadbelt, P. D. Iedema, Progress in Organic Coatings, 151 (2021), https://doi.org/10.1016/j.porgcoat.2020.106041

17. D. Gonze, and M. Kaufman, (2016), Chemical and Enzyme Kinetics.

18. D. Suhendra, E. R. Gunawan, A. D. Nurita, D. Komalasari, T. Ardianto, Journal of Oleo Science, 66(3), 209(2017), https://doi.org/10.5650/jos.ess16167

19. E. R. Gunawan, D. Suhendra, B. R. M. Hasanah, American Journal of Applied Science, 14(12), 1146(2017), https://doi.org/10.3844/ajassp.2017.1146.1151

20. E. R. Gunawan, D. Suhendra, M. Basri, Jurnal Natur Indonesia, 14(1), 37(2011), https://doi.org/10.31258/jnat.14.1.37-41

21. N. N. Ulusu, Journal of Molecular Evolution, 80, 251(2015), https://doi.org/10.1007/s00239-0159681-0

22. G. Gofferje, A. Stabler, T. Herfellner, U. Scheweiggert-Weisz E. Floter, Journal of Molecular Catalysis B: Enzymatic, 107, 1(2014), https://doi.org/10.1016/j.molcatb.2014.05.010

[RJC-5954/2020] 